\title{
Pyrido[4',3':4,5]pyrrolo[2,1-d][1,2,3,5]tetrazine a new class of Temozolomide heteroanalogues
}

\section{Patrizia Diana,* Antonina Stagno, Paola Barraja, Anna Carbone, Alessandra Montalbano, Annamaria Martorana, Gaetano Dattolo and Girolamo Cirrincione}

Dipartimento Farmacochimico Tossicologico e Biologico,Università degli Studi di Palermo, Via Archirafi 32, 90123 Palermo (Italy)

Email: diana@unipa.it

\begin{abstract}
A series of derivatives of new ring system pyrido[4',3':4,5]pyrrolo[2,1-d] $[1,2,3,5]$ tetrazine was obtained from moderate to excellent yields by reaction of 2-diazo-3-ethoxycarbonyl-pyrrolo[2,3c]pyridine with alkyl- or aryl-isocyanates in dichlorometane at room temperature or at $50{ }^{\circ} \mathrm{C}$ under microwave irradiation.
\end{abstract}

Keywords: Pyrido[4',3':4,5]pyrrolo[2,1-d][1,2,3,5]tetrazine, temozolomide, antitumor activity, microwave

\section{Introduction}

In the latest three decades azolotetrazine systems have attracted remarkable attention because of the outstanding antiproliferative activity exhibited by two imidazotetrazinone derivatives: mitozolomide and temozolomide.<smiles>[R]n1nnc2c(C(N)=O)ncn2c1=O</smiles>

Mitozolomide $\mathrm{R}=\mathrm{CH}_{2} \mathrm{CH}_{2} \mathrm{Cl}$

Temozolomide $\mathrm{R}=\mathrm{CH}_{3}$

\section{Figure 1}


Mitozolomide, the first azolotetrazinone to show good antitumor activity, reached the phase II clinical trials, but the recommended dose was too toxic and a deep platelet damage (thrombocytopenia) due to cross-linking of the two strands of the DNA, compromised its clinical use. $^{1-5}$

The 3-methyl congener, temozolomide, showed to be less potent but less toxic than mitozolomide and is now in the market with the trade name Temodal ${ }^{\circledR}$ used in patients affected by malignant melanoma, mycosis fungoides, and brain tumors. ${ }^{6-9}$ Temozolomide is a prodrug which undergoes, in the major groove of DNA, ring opening following the nucleophilic attack at $\mathrm{C}-4$ by a molecule of water to afford a monoalkyltriazene species which likely undergoes an $\mathrm{S}_{\mathrm{N}} 2$ alkylation at N-7 and/or O-6 sites of guanine. ${ }^{10}$

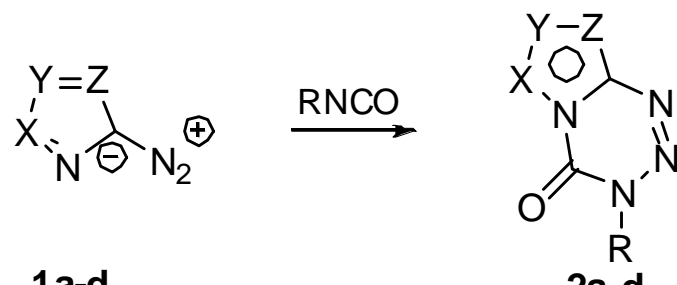
a $X=N, Y=Z=C R$ (pyrazole)
b $X=Y=N, Z=C R$ (triazole)
c $X=N, Y=Z=C$-benzofused (indazole)
d $X=Z=C R, Y=N$ (imidazole)

Scheme 1. Synthesis of azolotetrazinones.

The synthetic entry to azolotetrazinones was provided by Ege who reacted diazoazoles 1 with alkyl or aryl isocyanates at room temperature in the dark and in a non-hydroxylic solvent. Through this reaction the pyrazolotetrazinones $\mathbf{2 a}$, the 1,2,3-triazolotetrazinones $\mathbf{2 b}$ and indazolotetrazinones 2c were obtained. ${ }^{11}$

Later, several comprehensive reports describing the synthesis and the antineoplastic activity of many imidazo-tetrazinones 2d appeared, and further pyrazolo- and indazolo-tetrazinone derivatives were prepared using the same synthetic pathway (Scheme 1). ${ }^{1,12-15}$

The mechanism of this cycloaddition is not completely clarified. A fully concerted [4+2] mechanism, formerly proposed, ${ }^{11}$ seems unlikely since concerted mechanisms where heterocumulenes act as dipolarophiles have generally been discarded. ${ }^{16}$ A stepwise ionic pathway might involve either an initial nucleophilic attack at the isocyanate carbon, to give a dipolar intermediate which spontaneously undergoes ring closure or a [3+2] cycloaddition leading to a spiro compound which by a [1,5] sigmatropic rearrangement affords the bicyclic system (Scheme 2). ${ }^{1}$ 

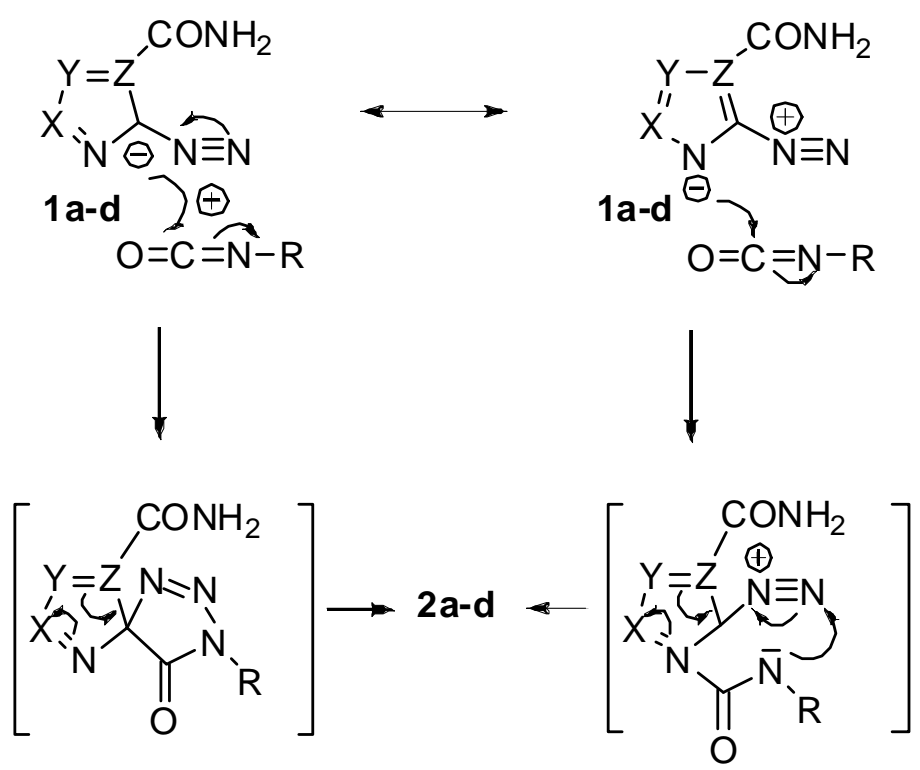

Scheme 2. Mechanism of cycloaddition.<smiles>[R]c1c([R])c2nnn([R])c(=O)n2c1[R]</smiles>

3<smiles>[R]c1c2ccccc2n2c(=O)n([R])nnc12</smiles>

4

Figure 2

Pyrrolotetrazinones 3, that hold the deaza skeleton of temozolomide, were prepared in good yield from the reaction of 2-diazopyrrole and isocyanate. ${ }^{17}$

However, more severe reaction condition were required, for the cycloaddition of the isocyanate to the 2-diazopyrroles: ten fold excess of isocyanates in dimethylformamide at room temperature in the dark for 24-72 $\mathrm{h}$. The reduced electrophility of the diazo group bound to the electron rich heterocycle justifies the use of a dipolar aprotic solvent and an excess of reactant. ${ }^{17}$ Pyrrolotetrazinones $\mathbf{3}$ exhibited a significant growth inhibition efficacy in many cancer cell lines, having $\mathrm{GI}_{50}$ values in the low micromolar or sub-micromolar range and reaching, in some cases nanomolar concentrations. ${ }^{18}$

Indolotetrazinones 4 were obtained in good yield from 2-diazoindoles using similar reaction conditions that allowed the isolation of the other azolo-tetrazinones: stoichiometric amount of isocyanates in DCM at room temperature for 1-2 hours. The ready reactivity of the 2diazoindoles was due to the most representative zwitterionic structure of these compounds 
bearing the negative charge on the $\mathrm{N}-1$ nitrogen which promotes the initial nucleophilic attack to the isocyanate carbon. ${ }^{19}$ Compounds 4 proved anti proliferative in the micromolar range. ${ }^{20}$

In this paper we focus our attention on the synthesis of the new ring system pyrido[4', $\left.3^{\prime}: 4,5\right]$ pyrrolo[2,1-d][1,2,3,5] tetrazine 5 by reaction of the key intermediate 2-diazo-3ethoxycarbonyl-pyrrolo[2,3-c]pyridine 10 with alkyl- or aryl-isocyanates.

\section{Results and Discussion}

The synthetic pathway to the new ring system started from the reaction between the 4-chloro-3nitropyridine 6 and the potassium enolate of ethyl cyanoacetate 7 to give 2-(3-nitropyridin-4-yl)3 -ethoxy-3-hydroxyacrilonitrile 8 in high yield (98\%). Reduction of this latter with iron and acetic acid at room temperature yielded the 2-amino-3-ethoxycarbonyl-pyrrolo[2,3-c]pyridine $\mathbf{9}$ (yield 88\%) (Scheme 3).
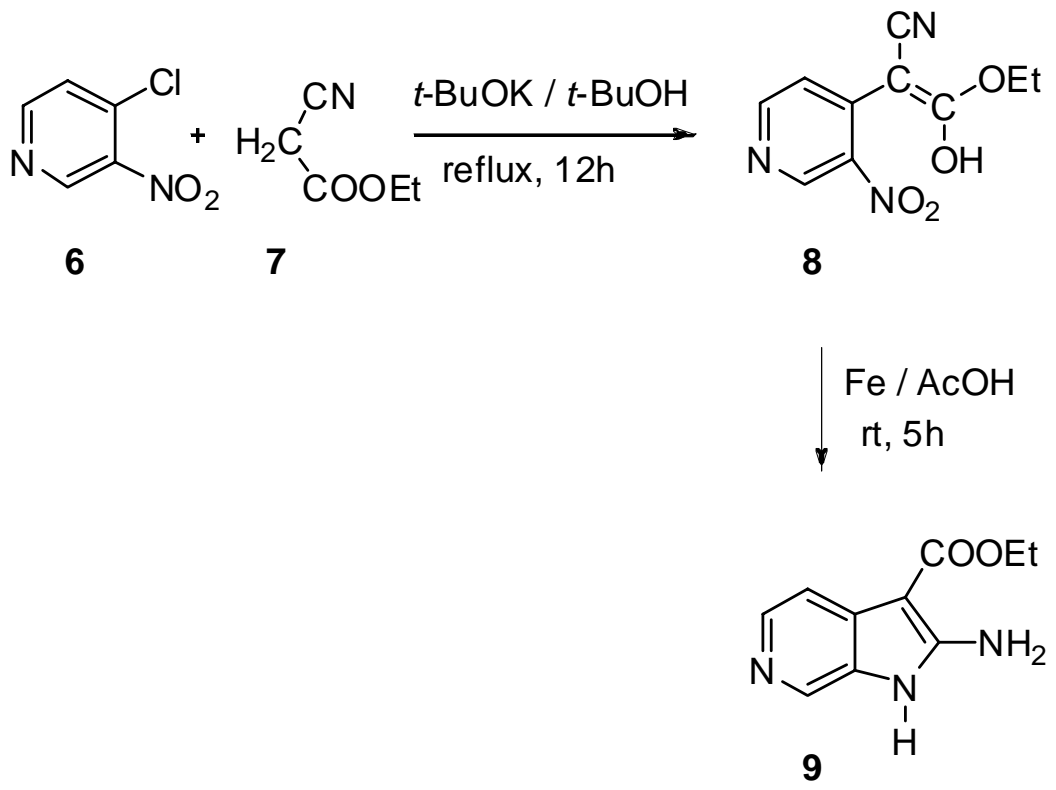

Scheme 3. Synthesis of 2-aminopyrrolopyridine 9.

The 2-diazo-3-ethoxycarbonylpyrrolo[2,3-c]pyridine $\mathbf{1 0}$ was obtained, in nearly preparative yield, by diazotization of the corresponding amine 9 and subsequent neutralization.

The reaction was carried out in acetic acid with stoichiometric amount of sodium nitrite under nitrogen atmosphere in the dark followed by addition of aqueous sodium carbonate. The strict control of the temperature at $0{ }^{\circ} \mathrm{C}$ both during diazotization and neutralization is crucial in obtaining high yield (Scheme 4). The ${ }^{1} \mathrm{H}$ and ${ }^{13} \mathrm{C}$ NMR spectra of the diazo compound $\mathbf{1 0}$ showed a pattern compatible with a $1 \mathrm{H}$-indole like structure bearing the negative charge on the pyrrole nitrogen. 


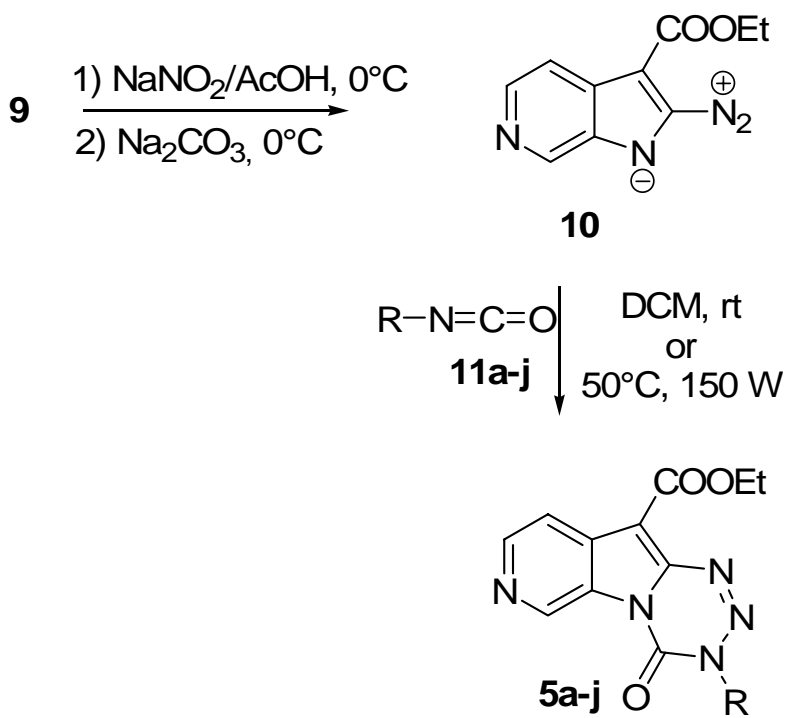

Scheme 4. Synthesis of pyridopyrrolotetrazines 5 .

The pyridopyrrolotetrazines $\mathbf{5 a - j}$ were prepared in moderate to good yields $(30-62 \%)$ by reaction of diazo 10 with stoichiometric amounts of the proper isocyanates 11a-j in DCM at room temperature for 12-48 $\mathrm{h}$. The same reactions carried out under microwave irradiation, with CEM discover apparatus, gave the pyridopyrrolotetrazines $\mathbf{5 a - j}$ with higher yield (62-87\%) in a much shorter time $(3 \mathrm{~min}$ ) (Table 1). The structure of derivatives 5 as well as of the intermediates $\mathbf{8 ,} \mathbf{9}$ and $\mathbf{1 0}$ was confirmed by spectroscopic data and elemental analysis.

Table 1. Synthesis of pyridopyrrolotetrazines 5

\begin{tabular}{cccccc}
\hline & & & & \multicolumn{2}{c}{ Yield \% } \\
\cline { 4 - 6 } Entry & Isocyanate & $\mathrm{R}$ & Product & $\mathrm{A}^{\mathrm{a}}$ & $\mathrm{B}^{\mathrm{b}}$ \\
\hline 1 & $\mathbf{1 1 a}$ & $\mathrm{C}_{6} \mathrm{H}_{5}$ & $\mathbf{5 a}$ & 34 & 67 \\
2 & $\mathbf{1 1 b}$ & $m-\mathrm{ClC}_{6} \mathrm{H}_{4}$ & $\mathbf{5 b}$ & 33 & 62 \\
3 & $\mathbf{1 1 c}$ & $o-\mathrm{ClC}_{6} \mathrm{H}_{4}$ & $\mathbf{5 c}$ & 36 & 70 \\
4 & $\mathbf{1 1 d}$ & $p-\mathrm{ClC}_{6} \mathrm{H}_{4}$ & $\mathbf{5 d}$ & 38 & 72 \\
5 & $\mathbf{1 1 e}$ & $m-\mathrm{OMeC}_{6} \mathrm{H}_{4}$ & $\mathbf{5 e}$ & 40 & 75 \\
6 & $\mathbf{1 1 f}$ & $o-\mathrm{OMeC}_{6} \mathrm{H}_{4}$ & $\mathbf{5 f}$ & 36 & 74 \\
7 & $\mathbf{1 1 g}$ & $\mathrm{CH}_{2} \mathrm{CH}_{2} \mathrm{Cl}$ & $\mathbf{5 g}$ & 54 & 82 \\
8 & $\mathbf{1 1 h}$ & $m-\mathrm{MeC}_{6} \mathrm{H}_{4}$ & $\mathbf{5 h}$ & 62 & 87 \\
9 & $\mathbf{1 1 i}$ & $c-\mathrm{Hexyl}$ & $\mathbf{5 i}$ & 38 & 76 \\
10 & $\mathbf{1 1 j}$ & $\mathrm{Me}$ & $\mathbf{5 j}$ & 30 & 68 \\
\hline
\end{tabular}

${ }^{\mathrm{a}} \mathrm{A}=$ conventional conditions. ${ }^{\mathrm{b}} \mathrm{B}=$ microwave irradiation. 
Four pyridopyrrolotetrazine derivatives $(\mathbf{5 d}, \mathbf{5 e}, \mathbf{5 h}, \mathbf{5} \mathbf{j})$, were selected for in vitro diseaseoriented antitumor screenings against the full NCI panel of about 60 human tumor cell lines that have grouped in disease sub-panel including leukemia, non-small lung, colon, central nervous system, melanoma, ovarian, renal, prostate, and breast tumors cell lines. ${ }^{21}$ The results obtained take into consideration the percent growth of the treated cells. Compounds 5 showed no significant activity with the exception of 5d which showed inhibitor activity against CCRFCEM, HL-60(TB) and SR of leukemia, OVCAR-8 of ovarian cancer, SF-295 of CNS cancer, and BT-549 and T-47D of breast cancer sub-panel cell lines, 5e which inhibited BT-549 of breast cancer sub-panel cell line, and $\mathbf{5 j}$ which was sensitive against A549/ATCC of non small cell lung cancer sub-panel cell line at $\mathrm{IC}_{50}$ value of $10^{-5} \mathrm{M}$.

\section{Conclusions}

In conclusion we have developed a highly efficient synthesis of the new ring system pyrido $\left[4^{\prime}, 3^{\prime}: 4,5\right]$ pyrrolo[2,1-d][1,2,3,5]tetrazine, by cycloaddition of isocyanates to the 2-diazo-3ethoxycarbonylpyrrolo[2,3-c]pyridine, using microwave irradiation.

\section{Experimental Section}

All melting points were taken on a Büchi-Tottoli capillary apparatus and are uncorrected; IR spectra were determined in bromoform with a Jasco FT/IR 5300 spectrophotometer; ${ }^{1} \mathrm{H}$ and ${ }^{13} \mathrm{C}$ NMR spectra were measured at 200 and $50.3 \mathrm{MHz}$, respectively in $\mathrm{DMSO}-d_{6}$ or $\mathrm{CDCl}_{3}$ solution, using a Bruker AC series $200 \mathrm{MHz}$ spectrometer (TMS as internal reference). Column chromatography was performed with Merck silica gel 230-400 Mesh ASTM or with Büchi Sepacore chromatography module (prepacked cartridge system). Elemental analyses (C, H, N) were within $\pm 0.4 \%$ of the theoretical values. Microwave experiments were carried out using a CEM Discover Labmate ${ }^{\mathrm{TM}}$ microwave apparatus.

Synthesis of 2-(3-nitropyridin-4-yl)-3-ethoxy-3-hydroxyacrylonitrile (8). To a stirred solution of $t$-BuOK $(0.85 \mathrm{~g}, 7.6 \mathrm{mmol})$ in $t$-BuOH $(10 \mathrm{~mL})$, ethyl cyanoacetate $7(\mathrm{~d}=1.063,0.88 \mathrm{~mL}, 8.3$ $\mathrm{mmol})$ was added. After $5 \mathrm{~min}$, a solution of 4-chloro-3-nitropyridine $6(0.60 \mathrm{~g}, 3.8 \mathrm{mmol})$ in $t$ $\mathrm{BuOH}$ was added and the mixture heated to reflux for $12 \mathrm{~h}$. The red solution was cooled to room temperature and the solvent was evaporated under reduced pressure. The residue was washed with $1 \mathrm{M}$ hydrochloric acid, water and recrystallized from methanol to give compound 8 as orange crystals, mp $178-179^{\circ} \mathrm{C}$, yield 98\%. IR: v $3558(\mathrm{OH}), 2200(\mathrm{CN}) \mathrm{cm}^{-1} .{ }^{1} \mathrm{H}$ NMR (DMSO$\left.d_{6}\right): \delta 1.18(\mathrm{t}, J=7.1 \mathrm{~Hz}, 3 \mathrm{H}), 4.07$ (q, J=7.1 Hz, 2H), 7.87-7.91 (m, 2H), $8.70(\mathrm{~s}, 1 \mathrm{H}), 13.39$ (bs, $\mathrm{OH}) .{ }^{13} \mathrm{C}$ NMR (DMSO-d $\left.)_{6}\right): \delta 14.4(\mathrm{q}), 59.5(\mathrm{t}), 117.6(\mathrm{~d}), 119.0(\mathrm{~s}), 135.7(\mathrm{~d}), 136.6(\mathrm{~s}), 137.9$ 
(d), 145.5 (2xs), 164.9 (s). Anal. Calcd for $\mathrm{C}_{10} \mathrm{H}_{9} \mathrm{~N}_{3} \mathrm{O}_{4}$ : C, 51.07; H 3.86; N, 17.87. Found: C, 51.24; H 3.72; N, 17.76 .

Synthesis of 2-amino-3(ethoxycarbonyl)pyrrolo[2,3-c]pyridine (9). Iron powder (1.50 g, 26.9 mmol) was added to a solution of $8(1.00 \mathrm{~g}, 4.3 \mathrm{mmol})$ in acetic acid $(7.5 \mathrm{~mL})$. The mixture was stirred at room temperature for $5 \mathrm{~h}$ and the solid formed was collected and recrystallized from ethanol to give amine 9: brown powder, mp 151-153 ${ }^{\circ} \mathrm{C}$, yield 88\%. IR: $v 3429$ and $3315\left(\mathrm{NH}_{2}\right.$ and $\mathrm{NH}), 1678(\mathrm{CO}) \mathrm{cm}^{-1} .{ }^{1} \mathrm{H}$ NMR (DMSO- $\left.d_{6}\right): \delta 1.34(\mathrm{t}, J=6.9 \mathrm{~Hz}, 3 \mathrm{H}), 4.27$ (q, J=6.9 Hz, 2H), 7.17-8.36 (m, 3H), 10.35 (bs, NH). ${ }^{13} \mathrm{C}$ NMR (DMSO-d $): \delta 14.6(\mathrm{q}), 58.5(\mathrm{t}), 84.2(\mathrm{~s})$, 112.4 (d), 129.3 (d), 129.4 (s), 133.3 (s), 139.1 (d), 165.2 (s), 172.2 (s). Anal. Calcd for $\mathrm{C}_{10} \mathrm{H}_{11} \mathrm{~N}_{3} \mathrm{O}_{2}$ : C, 58.53; H 5.40; N, 20.48. Found: C, 58.60; H 5.24; N, 20.25.

Synthesis of 2-diazo-3-ethoxycarbonyl-pyrrolo[2,3-c]pyridine (10). To a solution of 2-amino3-ethoxycarbonylpyrrolo[2,3-c]pyridine $9(0.62 \mathrm{~g}, 3 \mathrm{mmol})$ in glacial acetic acid $(6 \mathrm{~mL})$ a solution of sodium nitrite $(0.21 \mathrm{~g}, 3 \mathrm{mmol})$ in a small amount of water $(1 \mathrm{~mL})$ was added dropwise at $0{ }^{\circ} \mathrm{C}$ under nitrogen atmosphere. The mixture was neutralized at $0{ }^{\circ} \mathrm{C}$ with saturated $\mathrm{Na}_{2} \mathrm{CO}_{3}$ and the yellow solid precipitated was filtered off washed with water and dried under vacuum and in the dark. The crude product, quickly shaken in cyclohexane and filtered off, gave the 2-diazo-pyrrolo-pyridine 10, mp $168{ }^{\circ} \mathrm{C}$ dec, yield 98\%. IR: $v 2191\left(\mathrm{~N}_{2}{ }^{+}\right), 1709(\mathrm{CO}) \mathrm{cm}^{-1}$. ${ }^{1} \mathrm{H}$ NMR (DMSO-d $): 1.38(\mathrm{t}, J=7.0 \mathrm{~Hz}, 3 \mathrm{H}), 4.24$ (q, $\left.J=7.0 \mathrm{~Hz}, 2 \mathrm{H}\right), 7.75-8.59(\mathrm{~m}, 2 \mathrm{H}), 9.06$ (s, $1 \mathrm{H}) . \delta{ }^{13} \mathrm{C}$ NMR (DMSO-d $\left.)_{6}\right): \delta 14.1(\mathrm{q}), 60.9(\mathrm{t}), 114.4$ (s), 115.0 (d), 129.9 (s), 131.1 (s), 141.1 (d), 144.3 (s), 146.3 (d), 161.2 (s). Anal. Calcd for $\mathrm{C}_{10} \mathrm{H}_{8} \mathrm{~N}_{4} \mathrm{O}_{2}$ : C, 55.56; H 3.73; N, 25.91. Found: C, 55.17; H 3.92; N, 25.70.

General procedure for the synthesis of pyrido [4',3':4,5]pyrrolo[2,1-d][1,2,3,5]tetrazine-4(3H)-ones (5a-j)

A. Conventional conditions. To a solution of $\mathbf{1 0}(0.43 \mathrm{~g}, 2 \mathrm{mmol})$ in anhydrous DCM (10 $\mathrm{mL})$, the suitable isocyanate $11(2 \mathrm{mmol})$ in anhydrous DCM $(10 \mathrm{~mL})$ was added dropwise at room temperature in the dark under nitrogen atmosphere. The reaction mixture was stirred for 12-48 $\mathrm{h}$, then the solvent was evaporated under reduced pressure. The crude product was purified by column chromatography to afford the expected pyridopyrrolotetrazinone (5).

B. Microwave irradiation. A mixture of $\mathbf{1 0}(0.22 \mathrm{~g}, 1 \mathrm{mmol})$, the suitable isocyanate 11 (1 $\mathrm{mmol})$, and anhydrous DCM $(5 \mathrm{~mL})$ was irradiated at power of $150 \mathrm{~W}$, temperature of $50{ }^{\circ} \mathrm{C}$ for $3 \mathrm{~min}$. The solvent was evaporated under reduced pressure and the residue purified by column chromatography to give 5 .

Ethyl 3-phenyl-4-oxo-3,4-dihydropyrido[4',3':4,5]pyrrolo[2,1-d][1,2,3,5]tetrazine 10carboxylate (5a). According to the general procedure A the mixture was stirred for $24 \mathrm{~h}$ and the crude product was purified by chromatography using dichloromethane/ethylacetate (98:2) as eluent to afford $34 \%$ of 5 a as a pure yellow powder.

According to the general procedure B, the pyridopyrrolotetrazinone 5a was obtained in $67 \%$ yield. Mp 179-180 ${ }^{\circ} \mathrm{C}$. IR: $v 1753$ (CO), $1703(\mathrm{CO}) \mathrm{cm}^{-1} .{ }^{1} \mathrm{H}$ NMR (DMSO-d $)$ ): $\delta 1.43(\mathrm{t}, J=7.1$ $\mathrm{Hz}, 3 \mathrm{H}), 4.50$ (q, J=7.1 Hz, 2H), 7.61-7.74 (m, 5H), 8.28 (d, J=5.5 Hz, 1H), 8.75 (d, J=5.5 Hz, 
1H), $9.69(\mathrm{~s}, 1 \mathrm{H}) .{ }^{13} \mathrm{C}$ NMR (DMSO-d $): \delta 14.3(\mathrm{q}), 60.9(\mathrm{t}), 102.5(\mathrm{~s}), 116.0(\mathrm{~d}), 125.6(\mathrm{~s}), 126.6$ (2xd), 129.2 (2xd), 129.7 (d), 131.8 (s), 137.1 (s), 138.7 (d), 140.4 (s), 140.6 (s), 144.6 (d), 161.6 (s). Anal. Calcd for $\mathrm{C}_{17} \mathrm{H}_{13} \mathrm{~N}_{5} \mathrm{O}_{3}$ : C, 60.89; H 3.91; N, 20.89. Found: C, 60.71; H 4.14; N, 20.74.

Ethyl 3-(3-chlorophenyl)-4-oxo-3,4-dihydropyrido[4',3':4,5]pyrrolo[2,1-d][1,2,3,5]tetrazine10-carboxylate (5b). According to the general procedure $\mathbf{A}$ the mixture was stirred for $48 \mathrm{~h}$ and the crude product was purified by chromatography using cyclohexane/ethylacetate $(9: 1)$ as eluent to afford $33 \%$ of $\mathbf{5 b}$ as a pure yellow powder.

According to the general procedure $\mathbf{B}$, the pyridopyrrolotetrazinone $5 \mathbf{b}$ was obtained in $62 \%$ yield. Mp 114-115 ${ }^{\circ} \mathrm{C}$. IR: v 1747 (CO), 1722 (CO) $\mathrm{cm}^{-1} .{ }^{1} \mathrm{H}$ NMR (CDCl$\left.)_{3}\right): \delta 1.53$ (t, J=7.1 Hz, $3 \mathrm{H}), 4.60(\mathrm{q}, J=7.1 \mathrm{~Hz}, 2 \mathrm{H}), 7.53-7.65(\mathrm{~m}, 3 \mathrm{H}), 7.76(\mathrm{~s}, 1 \mathrm{H}), 8.32$ (d, J=5.6 Hz, 1H), 8.79 (d, $J=5.6 \mathrm{~Hz}, 1 \mathrm{H}), 9.88(\mathrm{~s}, 1 \mathrm{H}) .{ }^{13} \mathrm{C} \mathrm{NMR}\left(\mathrm{CDCl}_{3}\right): \delta 14.4(\mathrm{q}), 61.8(\mathrm{t}), 106.3(\mathrm{~s}), 116.6(\mathrm{~d}), 123.9$ (d), 126.0 (d), 126.1 (s), 129.9 (d), 130.4 (d), 132.6 (s), 135.1 (s), 137.6 (s), 139.0 (s), 139.7 (s), 139.8 (d), 145.3 (d), 161.8 (s). Anal. Calcd for $\mathrm{C}_{17} \mathrm{H}_{12} \mathrm{ClN}_{5} \mathrm{O}_{3}$ : C, 55.22; $\mathrm{H}$ 3.27; N, 18.94. Found: C, 55.09; H 3.39; N, 18.84.

Ethyl 3-(2-chlorophenyl)-4-oxo-3,4-dihydropyrido[4',3':4,5]pyrrolo[2,1-d][1,2,3,5]tetrazine10-carboxylate (5c). According to the general procedure $\mathbf{A}$ the mixture was stirred for $48 \mathrm{~h}$ and the crude product was purified by chromatography using cyclohexane/ethylacetate $(8: 2)$ as eluent to afford $36 \%$ of $5 \mathrm{c}$ as a pure yellow powder.

According to the general procedure B, the pyridopyrrolotetrazinone 5c was obtained in $70 \%$ yield. Mp 128-129 ${ }^{\circ} \mathrm{C}$. IR: $v 1747$ (CO), 1705 (CO) cm ${ }^{-1} .{ }^{1} \mathrm{H}$ NMR (DMSO-d $\left.)_{6}\right): \delta 1.44$ (t, $J=7.1$ $\mathrm{Hz}, 3 \mathrm{H}), 4.51$ (q, $J=7.1 \mathrm{~Hz}, 2 \mathrm{H}), 7.67-7.87(\mathrm{~m}, 4 \mathrm{H}), 8.31$ (dd, $J=5.61 .0 \mathrm{~Hz}, 1 \mathrm{H}), 8.78(\mathrm{~d}, J=5.6$ $\mathrm{Hz}, 1 \mathrm{H}), 9.68$ (d, $J=1.0 \mathrm{~Hz}, 1 \mathrm{H}) .{ }^{13} \mathrm{C} \mathrm{NMR}\left(\mathrm{DMSO}_{6}\right): \delta 14.2$ (q), 61.0 (t), 104.3 (s), 116.1 (d), 125.7 (s), 128.6 (d), 130.4 (d), 130.5 (d), 131.4 (s), 131.8 (s), 132.4 (d), 134.1 (s), 138.7 (d),

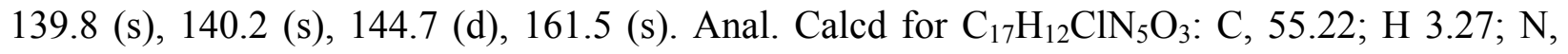
18.94. Found: C, 55.37; H 3.18; N, 18.84 .

Ethyl 3-(4-chlorophenyl)-4-oxo-3,4-dihydropyrido[4',3':4,5]pyrrolo[2,1-d][1,2,3,5]tetrazine10-carboxylate (5d). According to the general procedure $\mathbf{A}$ the mixture was stirred for $48 \mathrm{~h}$ and the crude product was purified by chromatography using cyclohexane/ethylacetate $(9: 1)$ as eluent to afford $38 \%$ of $\mathbf{5 d}$ as a pure yellow powder.

According to the general procedure B, the pyridopyrrolotetrazinone $\mathbf{5 d}$ was obtained in $72 \%$ yield. Mp 149-150 ${ }^{\circ} \mathrm{C}$. IR: $v 1743$ (CO), 1703 (CO) $\mathrm{cm}^{-1} .{ }^{1} \mathrm{H}$ NMR $\left(\mathrm{CDCl}_{3}\right): \delta 1.53(\mathrm{t}, \mathrm{J}=6.8 \mathrm{~Hz}$, $3 \mathrm{H}), 4.59$ (q, $J=6.8 \mathrm{~Hz}, 2 \mathrm{H}$ ), 7.56-7.70 (m, 4H), 8.31 (d, J=5.5 Hz, 1H), $8.78(\mathrm{~d}, J=5.5 \mathrm{~Hz}, 1 \mathrm{H})$, $9.87(\mathrm{~s}, 1 \mathrm{H}) .{ }^{13} \mathrm{C} \mathrm{NMR}\left(\mathrm{CDCl}_{3}\right): \delta 14.4(\mathrm{q}), 61.7(\mathrm{t}), 100.0(\mathrm{~s}), 106.1(\mathrm{~s}), 116.6(\mathrm{~d}), 126.0(\mathrm{~s})$, 127.0 (2xd), 129.7 (2xd), 132.5 (s), 135.2 (s), 135.8 (s), 139.1 (s), 140.0 (d), 145.3 (d), 161.8 (s). Anal. Calcd for $\mathrm{C}_{17} \mathrm{H}_{12} \mathrm{ClN}_{5} \mathrm{O}_{3}$ : C, 55.22; H 3.27; N, 18.94. Found: C, 55.13; H 3.36; N, 18.83 .

Ethyl 3-(3-methoxyphenyl)-4-oxo-3,4-dihydropyrido[4’,3’:4,5]pyrrolo[2,1-d][1,2,3,5 tetrazine-10-carboxylate (5e). According to the general procedure $\mathbf{A}$ the mixture was stirred for $48 \mathrm{~h}$ and the crude product was purified by chromatography using dichloromethane/ethylacetate (98:2) as eluent to afford $40 \%$ of $5 \mathbf{e}$ as a pure yellow powder. 
According to the general procedure $\mathbf{B}$, the pyridopyrrolotetrazinone 5e was obtained in $75 \%$ yield. Mp 124-125 ${ }^{\circ} \mathrm{C}$. IR: $v 1741$ (CO), $1702(\mathrm{CO}) \mathrm{cm}^{-1} .{ }^{1} \mathrm{H}$ NMR $\left(\mathrm{CDCl}_{3}\right): \delta 1.53(\mathrm{t}, J=6.9 \mathrm{~Hz}$, $3 \mathrm{H}), 4.58$ (q, J=6.9 Hz, 2H), 3.89 (s, 3H), 7.22-7.47 (m, 4H), 8.28-8.80 (m, 2H), $9.88(\mathrm{~s}, 1 \mathrm{H})$. ${ }^{13} \mathrm{C} \mathrm{NMR}\left(\mathrm{CDCl}_{3}\right): \delta 14.4(\mathrm{q}), 55.7(\mathrm{q}), 61.7$ (t), 100.0 (s), 105.7 (s), 111.7 (d), 115.7 (d), 116.6 (d), 118.1 (d), 126.1 (s), 130.1 (d), 132.6 (s), 137.7 (s), 139.3 (d), 139.9 (s), 145.2 (d), 160.3 (s), 161.9 (s). Anal. Calcd for $\mathrm{C}_{18} \mathrm{H}_{15} \mathrm{~N}_{5} \mathrm{O}_{4}$ : C, 59.18; H 4.14; N, 19.17. Found: C, 59.36; H 3.99; N, 18.98 .

Ethyl 3-(2-methoxyphenyl)-4-oxo-3,4-dihydropyrido[4',3':4,5]pyrrolo[2,1-d][1,2,3,5]tetrazine10-carboxylate (5f). According to the general procedure $\mathbf{A}$ the mixture was stirred for $48 \mathrm{~h}$ and the crude product was purified by chromatography using dichloromethane/ethylacetate (98:2) as eluent to afford $36 \%$ of $\mathbf{5 f}$ as a pure yellow powder.

According to the general procedure B, the pyridopyrrolotetrazinone $5 \mathbf{f}$ was obtained in $74 \%$ yield. Mp 138-139 ${ }^{\circ} \mathrm{C}$. IR: $v 1745(\mathrm{CO}), 1703(\mathrm{CO}) \mathrm{cm}^{-1} .{ }^{1} \mathrm{H} \mathrm{NMR}\left(\mathrm{CDCl}_{3}\right): \delta 1.43(\mathrm{t}, J=7.0 \mathrm{~Hz}$, $3 \mathrm{H}), 3.84$ (s, 3H), 4.50 (q, J=7.0 Hz, 2H), 7.18-7.68 (m, 4H), 8.29 (d, J=5.5 Hz, 1H,), 8.76 (d, $J=5.5 \mathrm{~Hz}, 1 \mathrm{H}), 9.67(\mathrm{~s}, 1 \mathrm{H}) .{ }^{13} \mathrm{C} \mathrm{NMR}\left(\mathrm{CDCl}_{3}\right): \delta 14.2(\mathrm{q}), 56.1(\mathrm{q}), 60.9(\mathrm{t}), 95.5(\mathrm{~s}), 103.3(\mathrm{~s})$, 112.8 (d), 116.1 (d), 120.8 (d), 125.2 (s), 129.3 (d), 132.0 (s), 132.1 (d), 138.6 (d), 139.8 (s), 140.5 (s), 144.3 (d), 154.8 (s), 161.5 (s). Anal. Calcd for $\mathrm{C}_{18} \mathrm{H}_{15} \mathrm{~N}_{5} \mathrm{O}_{4}$ : C, 59.18; H 4.14; N, 19.17. Found: C, 59.02; H 4.27; N, 19.23.

Ethyl 3-(2-chloroethyl)- 4-oxo-3,4-dihydropyrido[4',3':4,5]pyrrolo[2,1-d][1,2,3,5] tetrazine10-carboxylate (5g). According to the general procedure $\mathbf{A}$ the mixture was stirred for $48 \mathrm{~h}$ and the crude product was purified by chromatography using dichloromethane/ethylacetate (98:2) as eluent to afford $54 \%$ of $5 \mathrm{~g}$ as a pure yellow powder.

According to the general procedure $\mathbf{B}$, the pyridopyrrolotetrazinone $5 \mathbf{g}$ was obtained in $82 \%$ yield. Mp 108-109 ${ }^{\circ}$, IR: $v 1738(\mathrm{CO}), 1714(\mathrm{CO}) \mathrm{cm}^{-1} .{ }^{1} \mathrm{H}$ NMR $\left(\mathrm{CDCl}_{3}\right): \delta 1.52$ (t, J=7.1 Hz, $3 \mathrm{H}), 4.06$ (t, J=5.7 Hz, 2H), 4.59 (q, J=7.1 Hz, 3H), 4.88 (t, $J=5.7 \mathrm{~Hz}, 2 \mathrm{H}), 8.31$ (d, J=5.5 Hz, $1 \mathrm{H}), 8.78(\mathrm{~d}, J=5.5 \mathrm{~Hz}, 1 \mathrm{H}), 9.86(\mathrm{~s}, 1 \mathrm{H}) .{ }^{13} \mathrm{C} \mathrm{NMR}\left(\mathrm{CDCl}_{3}\right): \delta 14.4(\mathrm{q}), 40.8(\mathrm{t}), 50.8(\mathrm{t}), 61.7$ (t) $105.5(\mathrm{~s}), 116.5$ (d), 125.7 (s), 132.5 (s), 139.6 (s), 139.7 (d), 140.1 (s), 145.2 (d), 161.9 (s). Anal. Calcd for $\mathrm{C}_{13} \mathrm{H}_{12} \mathrm{ClN}_{5} \mathrm{O}_{3}$ : C, 48.53; H 3.76; N, 21.77. Found: C, 48.33; H 3.79; N, 21.53.

Ethyl 3-(3-methylphenyl)-4-oxo-3,4-dihydropyrido[4',3':4,5]pyrrolo[2,1-d][1,2,3,5]tetrazine-10carboxylate (5h). According to the general procedure A the mixture was stirred for $48 \mathrm{~h}$ and the crude product was purified by chromatography using dichloromethane/ethylacetate (98:2) as eluent to afford $62 \%$ of $5 \mathbf{h}$ as a pure yellow powder.

According to the general procedure $\mathbf{B}$, the pyridopyrrolo-tetrazinone 5 h was obtained in $87 \%$ yield. Mp 138-139 ${ }^{\circ} \mathrm{C}$, IR: $v 1741$ (CO), 1703 (CO) $\mathrm{cm}^{-1} .{ }^{1} \mathrm{H}$ NMR $\left(\mathrm{CDCl}_{3}\right): \delta 1.53$ (t, J=7.1 Hz, $3 \mathrm{H}), 2.49$ (s, 3H), 4.59 (q, J=7.1 Hz, 2H), 7.37-7.50 (m, 4H), 8.31 (dd, J=5.6 1.1 Hz, 1H), 8.77 $(\mathrm{d}, J=5.6 \mathrm{~Hz}, 1 \mathrm{H}), 9.88(\mathrm{~d}, 1 \mathrm{H}, J=1.1 \mathrm{~Hz}) .{ }^{13} \mathrm{C} \mathrm{NMR}\left(\mathrm{CDCl}_{3}\right): \delta 14.4(\mathrm{q}), 21.4(\mathrm{q}), 61.6(\mathrm{t})$, 105.5 (s), 116.5 (d), 123.0 (d), 126.0 (s), 126.4 (d), 129.2 (d), 130.6 (d), 132.6 (s), 136.6 (s), 149.4 (d), 139.7 (s), 139.8 (s), 140.0 (s), 145.2 (d), 161.9 (s). Anal. Calcd for $\mathrm{C}_{18} \mathrm{H}_{15} \mathrm{~N}_{5} \mathrm{O}_{3}$ : C, 61.89; H 4.33; N, 20.05. Found: C, 61.96; H 4.22; N, 20.15. 
Ethyl 3-cyclohexyl-4-oxo-3,4-dihydropyrido[4',3':4,5]pyrrolo[2,1-d][1,2,3,5] tetrazine-10carboxylate (5i). According to the general procedure A the mixture was stirred for $48 \mathrm{~h}$ and the crude product was purified by chromatography using dichloromethane/ethyl acetate (98:2) as eluent to afford $38 \%$ of $5 \mathbf{i}$ as a pure yellow powder.

According to the general procedure $\mathbf{B}$, the pyridopyrrolotetrazinone $5 \mathbf{i}$ was obtained in $76 \%$ yield. Mp 220-221 ${ }^{\circ} \mathrm{C}$, IR: v 1622 (CO), $1594(\mathrm{CO}) \mathrm{cm}^{-1} .{ }^{1} \mathrm{H}$ NMR $\left(\mathrm{CDCl}_{3}\right)$ : $\delta$ 1.05-2.12 (m, $14 \mathrm{H}), 4.58$ (q, $J=7.1 \mathrm{~Hz}, 2 \mathrm{H}), 8.31(\mathrm{dd}, J=5.61 .1 \mathrm{~Hz}, 1 \mathrm{H}), 8.76(\mathrm{~d}, J=5.6 \mathrm{~Hz}, 1 \mathrm{H}), 9.88(\mathrm{~d}, J=$ $1.1 \mathrm{~Hz}, 1 \mathrm{H}) .{ }^{13} \mathrm{C} \mathrm{NMR}\left(\mathrm{CDCl}_{3}\right): \delta 14.5(\mathrm{q}), 25.0(\mathrm{t}), 25.6(2 \mathrm{xt}), 31.9(2 \mathrm{xt}), 58.6(\mathrm{~d}), 61.5(\mathrm{t})$, 116.4 (d), 125.6 (s), 132.7 (s), 139.6 (s), 139.7 (d), 145.0 (d), 148.6 (s), 156.7 (s), 162.2 (s). Anal. Calcd for $\mathrm{C}_{17} \mathrm{H}_{19} \mathrm{~N}_{5} \mathrm{O}_{3}$ : C, 59.81; H 5.61; N, 20.52. Found: C, 59.57; H 5.88; N, 20.29.

Ethyl 3-methyl-4-oxo-3,4-dihydropyrido[4',3':4,5]pyrrolo[2,1-d][1,2,3,5]tetrazine-10carboxylate (5j). According to the general procedure A the mixture was stirred for $48 \mathrm{~h}$ and the crude product was purified by chromatography using dichloromethane/ethylacetate (98:2) as eluent to afford $30 \%$ of $5 \mathbf{j}$ as a pure yellow powder.

According to the general procedure $\mathbf{B}$, the pyridopyrrolotetrazinone $5 \mathbf{j}$ was obtained in $68 \%$ yield. Mp 176-177 ${ }^{\circ} \mathrm{C}$, IR: $v 1730$ (CO), 1697 (CO). $\mathrm{cm}^{-1} .{ }^{1} \mathrm{H}$ NMR $\left(\mathrm{CDCl}_{3}\right): \delta 1.52$ (t, J=7.1 Hz, $3 \mathrm{H}), 4.17(\mathrm{~s}, 3 \mathrm{H}), 4.58$ (q, J=7.1 Hz, 2H), 8.31 (d, J=5.7 Hz, 1H), 8.77 (d, 1H, J=5.7 Hz), 9.87 $(\mathrm{s}, 1 \mathrm{H}) .{ }^{13} \mathrm{C} \mathrm{NMR}\left(\mathrm{CDCl}_{3}\right): \delta 14.3(\mathrm{q}), 37.0(\mathrm{q}), 60.7(\mathrm{t}), 101.5(\mathrm{~s}), 115.8(\mathrm{~d}), 125.0(\mathrm{~s}), 131.7(\mathrm{~s})$, 138.6 (d), 140.7 (s), 141.3 (s), 144.4 (d), 161.7 (s). Anal. Calcd for $\mathrm{C}_{12} \mathrm{H}_{11} \mathrm{~N}_{5} \mathrm{O}_{3}: \mathrm{C}, 52.75 ; \mathrm{H}$ 4.06; N, 25.63. Found: C, 52.51; H 4.22; N, 25.33.

\section{Acknowledgements}

This work was financially supported by Ministero dell'Istruzione dell'Università e della Ricerca.

\section{References}

1. Stevens, M. F. G.; Hickman, J. A.; Stone, R.; Gibson, N. W.; Baig, G. U.; Lunt, E.; Newton, C. G. J. Med. Chem. 1984, 27, 196.

2. Hickman, J. A.; Stevens, M. F. G.; Gibson, N. W.; Langdon, S. P.; Fizames, C.; Lavelle, F.; Atassi, G.; Lunt, E.; Tilson, R. M. Cancer Res. 1985, 45, 3008.

3. Fodstad, O.; Aamdal, S.; Pihl, A.; Boyd, M. R. Cancer Res. 1985, 45, 1778.

4. Newlands, E. S.; Blackledge, G. R. P.; Slack, J. A.; Goddard, C.; Brindley, C. J.; Holden, L.; Stevens, M. F. G. Cancer Treat. Rep. 1985, 69, 801.

5. Stevens, M. F. G.; Newlands, E. S. Eur. J. Cancer 1993, 29A, 1045.

6. Lowe, P. R.; Sansom, C. E.; Schwalbe, C. H.; Stevens, M. F. G.; Clark, A. S. J. Med. Chem. 1992, 35, 3377. 
7. Newlands, E. S.; Stevens, M. F. G.; Wedge, S. R.; Wheelhouse, R. T.; Brock, C. Cancer Treat. Rep. 1997, 23, 35.

8. Suppasansatorn, P.; Wang, G.; Conway, B. R.; Wang, W.; Wang, Y. Cancer Lett. 2006, 244, 42.

9. Barone, G.; Maurizi, P.; Tamburrini, G.; Riccardi, R. Childs Nerv. Syst. 2006, 22, 652.

10. Denny, B. J.; Wheelhouse, R. T.; Stevens, M. F. G.; Tsang, L. L. H.; Slack, J. A. Biochemistry 1994, 33, 9045.

11. Ege, G.; Gilbert, K. Tetrahedron Lett. 1979, 20, 4253.

12. Stevens, M. F. G. in New Avenues in Developmental Cancer Chemotherapy; Harrap, K. R.; Connors, T. A., Eds.; Bristol-Myers Cancer Symposium Vol 8; Academic Press: Orlando, Florida, USA, 1987; p 345.

13. Lunt, E.; Newton, C. G.; Smith, C.; Stevens, G. P.; Stevens, M. F. G.; Straw, C. G.; Walsh, R. J. A.; Warren, P. J.; Fizames, C.; Lavelle, F.; Langdon, S. P.; Vickers, L. M. J. Med. Chem. 1987, 30, 357.

14. Cheng, C. C.; Elslanger, E. F.; Werbel, L. M.; Priebe, S. R.; Leopold, W. R. J. Med. Chem. 1986, 29, 1544.

15. Ege, G.; Gilbert, K.; Maurer, K. Chem. Ber. 1987, 120, 1375.

16. Gilchrist, T. L.; Storr, R. C. in Organic Reactions and Orbital Symmetry, $2^{\text {nd }}$ Edn.; Cambridge University Press, 1979; p 201.

17. Diana, P.; Barraja, P.; Lauria, A.; Almerico, A. M.; Dattolo, G.; Cirrincione, G. Synthesis 1999, 12, 2082.

18. Diana, P.; Barraja, P.; Lauria, A.; Montalbano, A.; Almerico, A. M.; Dattolo, G.; Cirrincione, G. Bioorg. Med. Chem. 2003, 11, 2371.

19. Barraja, P.; Diana, P.; Lauria, A.; Almerico, A. M.; Dattolo, G.; Cirrincione, G. Helv. Chim. Acta 2001, 84, 2212.

20. Barraja, P.; Diana, P.; Lauria, A.; Montalbano, A.; Almerico, A. M.; Dattolo, G.; Cirrincione, G. Bioorg. Med. Chem. 2005, 13, 295.

21. Monks, A.; Scudiero, D.; Skehan, P.; Shoemaker, R.; Paull, K.; Vistica, D.; Hose, C.; Langely, J.; Cronise, P. Vaigro-Wolff, A.; Gray-Goodrich, M.; Campbell, H.; Mayo, J.; Boyd, M. R. J. Natl. Cancer Inst. 1991, 83, 757. 